\title{
Research on Effects of Basic Pension Scheme on Household Debt Behavior
}

\author{
Shengyun Yan \\ Economic School, Jinan University, Guangzhou, China \\ Email: yanshengyun1018@163.com
}

How to cite this paper: Yan, S.Y. (2019) Research on Effects of Basic Pension Scheme on Household Debt Behavior. Modern Economy, 10, 931-944.

https://doi.org/10.4236/me.2019.103062

Received: February 28, 2019

Accepted: March 22, 2019

Published: March 25, 2019

Copyright $\odot 2019$ by author(s) and Scientific Research Publishing Inc. This work is licensed under the Creative Commons Attribution International License (CC BY 4.0).

http://creativecommons.org/licenses/by/4.0/

\section{c) (i) Open Access}

\begin{abstract}
The current scale of debt of Chinese families has expanded rapidly in recent years. This article discusses the macro factors influencing household debt-basic pension insurance and verifies their relationship. Based on the micro-data of the 2014 China Family Tracking Survey, this paper analyzes the impact of China's basic endowment insurance on household debt behavior. Using Tobit model regression, it is found that the basic pension insurance has significant positive effects on household debt level under the overall sample. Further sub-sample research on the heterogeneity characteristics of families shows, the positive correlation between basic pension insurance and household debt ratio exists in rural households and high-income families. At last, the above conclusions were confirmed by IV-Tobit regression using the average contribution rate and the institutional dependency ratio of the province where the family is located as an instrumental variable. This shows that although the increase in social security coverage has enhanced the family's ability to counter risk, it also needs to prevent the negative externalities brought about by excessive debt of residents.
\end{abstract}

\section{Keywords}

Basic Pension Scheme, Household Debt, Degree of Debt, CFPS

\section{Introduction}

Social insurance is the core of China's multi-level social security system, among which basic pension insurance is the one with the widest coverage and the largest expenditure. According to National bureau of statistics of China, the number of people participating in basic pension scheme increased by $24.66 \%$ from 2012 to 2016 , with an average annual growth rate of $5.68 \%{ }^{1}$. Meanwhile, China's old-age dependency ratio has reached $15 \%$ in 2016. Basic pension insurance, as the main ${ }^{1}$ The data comes from the website of the National Bureau of Statistics. 
economic source of retired people, will inevitably have an impact on their consumption and saving behaviors

The fact that household savings have fallen sharply while social consumption growth has slowed down is worth noting. One of the most important reasons is the rapid growth of household debts. From 2015 to 2017, the leverage ratio of Chinese residents rose quickly from $39.5 \%$ to $49 \%^{2}$.

From this point of view, the expansion of household debtscale is basically in sync with the spread of basic pension insurance. Therefore, there must be some relationship between the two. Actually the family's lending behavior is a loss compensation secured by the family's future income from a third party. According to the background risk theory, pension insurance can lower labor income risk by making up for the lack of income in the future due to retirement. So the basic endowment insurance system, as one of the important channels for residents' risk sharing, will inevitably have an impact on residents' debt behavior. But most of the existing relevant literatures still focus on the impact of basic pension insurance on residents' consumption and saving behaviors. Consequently, it still needs to be further studied on how the basic pension insurance acts on residents' borrowing behavior.

According to many empirical studies, income has a significant positive impact on household debt levels, while the basic endowment insurance has a great influence on the families' current and future income. The income effect of pension insurance is beneficial for reducing labor income risk and eliminating the uncertainty of future income. At the same time, pension insurance contributions will reduce the current disposable income. Since the family cannot use the pension wealth to make mortgage loans, there will be a crowding-out effect. Based on the above inference, basic pension insurance is likely to affect residents' debt behavior by changing current and future income. In addition, under the expectation of rising housing prices in China in recent years, it is more common for families to invest in real estate through debt financing and to increase consumption by means of housing appreciation. And different income and pension security level will influence the function of basic endowment insurance on income, thus changing the residents' behavior.

Therefore, the study of this paper, on the one hand, further investigates how the basic pension scheme affects residents' subjective debt behavior as a macroeconomic variable; on the other hand, by figuring out the cause-and-effect relationship between the two variables, we can study the spillover effect of improving the endowment insurance coverage.

\section{Literature Review}

\subsection{Factors Affecting Household Debt Behavior}

As one of the most basic but crucial micro-structure in the national economy, ${ }^{2}$ The data comes from the report on China's deleveraging progress in 2017 released by the national laboratory of finance and development of the Chinese academy of social sciences and the national balance sheet research center. 
the family's debt behavior will inevitably be influenced by both microcharacteristics and macroenvironment. Foreign studies on the factors affecting household debt have been relatively mature, and it is believed that household debt behavior will be affected by family characteristics and social institutional environment. First, the demographic characteristics of the family is an important factor [1], which mainly includes the population size and age of householder, marital status, education and health level. In addition, Zhang Jianjie [2] also believes that the family's social network will have an impact on farmers' financial lending behavior.

Second, the impact of family wealth and income cannot be ignored. Many empirical studies have verified that household debt is positively correlated with income. For example, Crook [3] found households with real estate or higher income have stronger demand for debt. Hu Zhen et al. [4] found that this positive incentive has different influence on families with different debt levels. And Wu Weixing [5] further discovered that this positive correlation exists only when the household debt scale is high, while the households with other low-liability scales are not significant.

Compared with family income, the impact of family assets on family liabilities is more complicated, especially for housing with dual attributes of consumer goods and investment products. Wu Weixing [6] introduced the concept of household financial leverage and proved that household assets with higher total assets have higher yields, but their debt costs are lower. Hu Zhen [4] further analyzed the effects and believed that the increase of asset holdings can significantly reduce the willingness of household debt, and the stronger the investment property of assets, the more significant this effect will be.

Generally, most of the existing researches analyze the causes of household debt behavior from individual heterogeneity characteristics, but ignore the impact of the macroeconomic policy. The empirical model in this paper introduces the household participation rate of basic pension insurance, and controlled the above factors. In addition, since there is a mutual influence between participation behavior of basic pension insurance and household debt behavior, endogenous problems need to be solved by means of instrumental variables.

\subsection{The Mechanism of Basic Pension Insurance Affecting Household Debt Behavior}

Basic endowment insurance is not only a significant channel for residents' risk sharing, but also a kind of compulsory savings for the family. And it will affect the family's current income and future income, thus affecting the family's debt behavior. On the one hand, permanent income theory from Friedman argues that social security could change household income expectations, which induces positive incentives for household consumption. Moreover, precautionary saving theory from Leland explained from another perspective, the reason why social insurance promotes consumption is residents reduce their precautionary savings due to lower uncertainty about future income and expenditures. Further, the 
impact of social endowment insurance on household consumption varies among different income groups [7] [8]. On the other hand, Zeldes [9] studied the impact of current income, and found that the current pension insurance premiums squeezed the current income, as the pension wealth cannot be used as a mortgage asset hence generating borrowing constraints. Besides this constraint effect is stronger among young people with lower average incomes in their lifetime [10].

The impact of income on household debt choices is also different. The more optimistic the family expects future income growth, the stronger the future solvency will be. Under this circumstance, families are inclined to increase their liabilities to meet current consumption. Cox and Jappeli [11] found that household expectations of future income growth would determine whether they loaned. However, He Lifen [12] did the opposite, and found that income expectations had no significant effect on household debt. Simultaneously many studies show that current income will affect household debt. Sebastian \& Young [1] found that low-income households are more likely to borrow than high-income households, but this relationship varies with debt scale. The positive relationship between debt size and income exists only in highly indebted households, and there is no significant correlation in small or medium-denominated households.

\section{Theoretical Analysis and Research Hypothesis}

\subsection{Theoretical Analysis}

The basic pension scheme, as a system of state-enforced private savings, will inevitably have different effects on the family's current and future incomes, thus exerting an influence on household debt behavior. It has two distinct effects on income: First, the income effect, that is, pension wealth changes the family's budget constraints and raises the expected income level of residents in the future [13]. This will reduce future income risks and generates positive incentives for borrowing behaviors. The higher the level of protection, the stronger the incentive effect.

The second is the crowding out effect. The pension insurance contributions will occupy the current disposable income of the residents, and the residents cannot use the pension as a mortgage to borrow, which forms the borrowing constraint [9] and limits the family's borrowing behavior. Therefore, the basic endowment insurance is a key factor of the debt behavior of residents. The correlation between the two depends on the comparison of income effect and crowding effect of basic endowment.

\subsection{Research Hypothesis}

Under the endowment insurance system for urban working group, employees contribute $8 \%$ of their salary. Then the base pay of endowment insurance for urban and rural residents is divided into 12 grades. The minimum per person is 100 yuan per year, the highest is 2000 yuan. Overall, the pension insurance pre- 
miums paid by urban and rural residents account for a small proportion of personal disposable income, hence the crowding out effect is very limited. On the other hand, after paying the endowment insurance premiums, urban and rural residents will receive stable pensions in the future, as a result the income effect will be more obvious. For this reason, hypothesis 1 is proposed:

H1: Under the total sample, basic pension coverage has a significant impact on household debt level.

In February 2014, the two separate pension systems for urban and rural residents was unified. The company's retirees receive a pension of 2061 yuan per month while non-employed insured residents receive a pension of 90 in 2014. Consequently, compared with the pension scheme for working people, the treatment of the pension scheme for non-working residents is quite low. Nie Jianliang [14] argue that most of people attended the pension scheme for non-working residents are inclined to the lowest level of payment. The basic old-age insurance for non-working residents implements the principle of "Those who contribute more will get more". So this means those insured rural residents facing high risks could get extra government subsidies, which will increase farmers' income expectations and enhance their income effects. Besides, rural residents prefer to the lower level of payment. In sum, with the increase of their net income, the effects of crowding out is small, which results in positive correlation.

For urban residents, as analyzed in the previous section, the income effect of basic pension insurance may be also greater than the crowding out effect, so the willingness of basic pension insurance may have an incentive effect on household debt. However, the willingness to have a debt does not necessarily result in a substantial liability. Compared with the acquaintance society in rural areas, it is difficult for urban households to borrow funds from other people or financial institutions. Therefore, the actual level of debt of urban households with willingness to be in debt is not high. For this reason, hypothesis 2 is proposed:

$\mathrm{H} 2$ : The coverage of basic endowment insurance has a positive incentive to the debt level of rural households, but it may not have a significant impact on the actual debt level of urban households.

Although the old-age insurance premium is not high in comparison with National per capita annual income, the proportion of pension insurance cost in the income of poor families is still larger than wealthy families, which means greater crowding out effect. On the other hand, the preference of low level of premium refers to low expectation of future pension. Even so, when poor households are usually prone to economic plight, pension insurance will motivate household debt behavior. Of course, it is not so easy for poor households to achieve debt relative to high-income families.

For high-income families, the relatively high disposable income level improves the credit constraint problem they face. And the better system security level makes them relatively optimistic about future income growth. At this time the income effect of pension insurance may be greater than the crowding out ef- 
fect, which has an incentive effect on household debt willingness and debt level.

H3: Basic pension insurance has a positive impact on the level of debt of both low-income families and high-income families; however, the former is not as significant as the latter.

\section{Indicator Selection and Data Description}

The micro-data of sample family in this paper are derived from China Family Panel Studies (CFPS) conducted by Institute of Social Science Survey in 2014. The database has a total of 13,831 household samples, including 6789 urban families and 7042 rural households. In order to prevent the interference of outliers, this paper excludes the sample of the lowest $1 \%$ and the highest $1 \%$ of the $t$ indicators of family debt and house asset. Then 8720 sample data are obtained. Data processing and empirical analysis were implemented using Stata13.0. In view of the availability of data and the needs of research, the following indicators were selected and constructed:

1) Explained variable: household debt. Household debt can be measured by the debt, that is, the proportion of household debt in household assets.

2) Core explanatory variables: the basic endowment insurance. Basic endowment insurance is measured by eldinsurance, that is, the proportion of the number of people participating in basic endowment insurance (including urban job insurance, urban residence insurance and new rural cooperative insurance) in the family size.

3) Personal characteristic of householder control variable: Since there is no concept of head of household in the design of CFPS questionnaire, this paper defines the concept of householder as the decision maker of household savings, investment and insurance. Personal characteristic of householder includes gender, edu, age, marriage, rural, health. Specifically, if householder is male, the value of gender is 1 , otherwise it is 0 . edu represents the length of education, and marriage indicates the marital status of householder. The value of marriage is 1 when householder married, otherwise it is 0 . Rural means the type of household registration. If the householder's registration is agricultural family, the value of Rural is 1 , otherwise it is 0 . Health represents the health status of householder, which is divided into 1 to 5 different grades. The most healthy is 1 , and the worst is 5 .

4) Family demographic characteristics control variable: Family demographic characteristics involves Population, Work, Hospital, Socialnet, Cominsurance. Specifically, Population indicates the number of permanent residents in the family; Work indicates the proportion of the family employed in family size; Hospital implies whether family members have been hospitalized in the past 12 months, and if so, the value of hospital is 1 , otherwise it is 0.Socialnet indicates social network relationships. If the family has loans with relatives and friends, the value is 1 . Cominsurance represents the family's commercial insurance expenditures in the past 12 months. 
5) Household assets control variable: Several indicators have been selected for family assets, such as income, consume, houseasset, finasset. Income represents total household income, consume meanstotal household consumption expenditure, houseasset represents property holding value, and finasset represents the ratio of financial assets to total household assets.

Besides, the indicator such as income, consume, houseasset, cominsurance was included in the regression equation in the form of logarithmic. Descriptive statistics for the main variables are shown in Table 1.

As can be seen from Table 1, the number of permanent residents in the household is 2.65 , which means the majority of the survey samples are families of three. Moreover, the average proportion of the employed population is relatively high with a stable source of income. The average sample household income is much higher than the 2014 national per capita disposable income of 20,167 yuan. In addition, the total value of household assets is not low, of which the property contribution is the largest. It is worth mentioning that the logarithmic average of family commercial insurance expenditure is only 1.628 yuan, which fully shows that the scale of individual or family participation in commercial endowment insurance in China in 2014 is still small. So the coverage of commercial endowment insurance is relatively small compared with basic endowment insurance, which is difficult to meet the needs of family endowment security.

Table 1. Descriptive statistics.

\begin{tabular}{|c|c|c|c|c|}
\hline Variable name & Mean & Standard Deviation & Min & $\operatorname{Max}$ \\
\hline debt & 0.132 & 0.400 & 0 & 3 \\
\hline eldinsurance & 0.286 & 0.301 & 0 & 1 \\
\hline gender & 0.624 & 0.484 & 0 & 1 \\
\hline age & 50.035 & 14.127 & 16 & 92 \\
\hline edu & 7.543 & 4.58 & 0 & 22 \\
\hline rural & 0.707 & 0.455 & 0 & 1 \\
\hline marriage & 0.854 & 0.353 & 0 & 1 \\
\hline population & 2.697 & 1.848 & 1 & 17 \\
\hline health & 3.067 & 1.228 & 1 & 5 \\
\hline lnincome & 10.281 & 1.291 & 0 & 15.653 \\
\hline lnconsume & 10.324 & 0.922 & 3.401 & 13.964 \\
\hline lnhouseasset & 11.825 & 1.509 & 4.605 & 16.649 \\
\hline finasset & 0.127 & 0.247 & 0 & 1 \\
\hline Incominsurance & 1.628 & 3.212 & 0 & 12.206 \\
\hline work & 0.496 & 0.312 & 0 & 1 \\
\hline hospital & 0.230 & 0.421 & 0 & 1 \\
\hline socialnet & 0.378 & 0.485 & 0 & 1 \\
\hline
\end{tabular}




\section{Research Design and Empirical Analysis}

\subsection{Research Model Design}

Since the ratio of debt to total household assets in the sample is 0 , there is a case of sample truncation. If OLS is used to linearly regress the whole sample, it will lead to inconsistent estimation. Therefore, the Tobit model is more accurate, and its form is as follows:

$$
y_{i}^{*}=\alpha+\beta_{1} X_{i}+\beta_{2} Z_{i}+\varepsilon_{i}
$$

$y_{i}^{*}$ represents household debt ratio. $X_{i}$ indicates the proportion of participants in basic pension insurance in family size; $Z_{i}$ indicates other control variables of household debt, including householder's characteristics, household demographic characteristics, and household asset status; $\varepsilon_{i}$ indicates random error term.

\subsection{Empirical Analysis}

The empirical results are shown in Table 2.

Table 2. Analysis of regression coefficient of basic endowment insurance for different characteristic households.

\begin{tabular}{|c|c|c|c|c|c|}
\hline & Tobit & $\begin{array}{l}\text { Urban } \\
\text { families }\end{array}$ & $\begin{array}{c}\text { Rural } \\
\text { families }\end{array}$ & $\begin{array}{l}\text { High-income } \\
\text { families }\end{array}$ & $\begin{array}{l}\text { Low-income } \\
\text { families }\end{array}$ \\
\hline & (1) & $(2)$ & (3) & (4) & (5) \\
\hline \multirow[t]{2}{*}{ eldinsurance } & $0.109^{* * *}$ & 0.047 & $0.140^{* * *}$ & $0.086^{* * *}$ & $0.099^{*}$ \\
\hline & $(0.027)$ & $(0.035)$ & $(0.039)$ & $(0.028)$ & $(0.051)$ \\
\hline \multirow[t]{2}{*}{ gender } & -0.015 & 0.015 & -0.033 & -0.011 & -0.019 \\
\hline & $(0.016)$ & $(0.020)$ & $(0.024)$ & $(0.016)$ & $(0.033)$ \\
\hline \multirow[t]{2}{*}{ age } & $-0.003^{\star * *}$ & $-0.004^{* * *}$ & -0.001 & $-0.002^{* * *}$ & $-0.003^{\star *}$ \\
\hline & $(0.001)$ & $(0.001)$ & $(0.001)$ & $(0.001)$ & $(0.001)$ \\
\hline \multirow[t]{2}{*}{ edu } & $0.009^{* * *}$ & $0.011^{\star * *}$ & $0.006^{\star *}$ & $0.005^{\star * *}$ & $0.013^{\star * *}$ \\
\hline & $(0.002)$ & $(0.003)$ & $(0.003)$ & $(0.002)$ & $(0.004)$ \\
\hline \multirow[t]{2}{*}{ rural } & $-0.048^{\star \star}$ & $-0.049^{\star *}$ & 0.018 & $-0.048^{\star *}$ & -0.074 \\
\hline & $(0.021)$ & $(0.023)$ & $(0.046)$ & $(0.019)$ & $(0.048)$ \\
\hline \multirow[t]{2}{*}{ marriage } & -0.012 & 0.007 & -0.000 & 0.011 & -0.030 \\
\hline & $(0.025)$ & $(0.031)$ & $(0.038)$ & $(0.028)$ & $(0.045)$ \\
\hline \multirow[t]{2}{*}{ population } & 0.004 & 0.003 & 0.007 & -0.004 & $0.020^{*}$ \\
\hline & $(0.005)$ & $(0.007)$ & $(0.007)$ & $(0.005)$ & $(0.011)$ \\
\hline \multirow[t]{2}{*}{ health } & 0.009 & 0.000 & 0.009 & -0.002 & $0.026^{* *}$ \\
\hline & $(0.006)$ & $(0.009)$ & $(0.009)$ & $(0.006)$ & $(0.012)$ \\
\hline \multirow[t]{2}{*}{ lnincome } & $-0.113^{\star \star \star *}$ & $-0.185^{\star \star \star}$ & -0.064 & -0.194 & 0.011 \\
\hline & $(0.038)$ & $(0.058)$ & $(0.051)$ & $(0.238)$ & $(0.074)$ \\
\hline lnincome2 & $0.006^{* * *}$ & $0.010^{* * *}$ & 0.003 & 0.011 & -0.002 \\
\hline
\end{tabular}




\begin{tabular}{|c|c|c|c|c|c|}
\hline \multicolumn{6}{|l|}{ Continued } \\
\hline & $(0.002)$ & $(0.003)$ & $(0.003)$ & $(0.010)$ & $(0.005)$ \\
\hline \multirow[t]{2}{*}{ lnconsume } & $0.107^{\star \star \star}$ & $0.092^{* * *}$ & $0.114^{\star * *}$ & $0.078^{\star * *}$ & $0.126^{* * *}$ \\
\hline & $(0.011)$ & $(0.014)$ & $(0.015)$ & $(0.011)$ & $(0.021)$ \\
\hline \multirow[t]{2}{*}{ lnhouseasset } & $-0.115^{\star \star *}$ & $-0.124^{\star * *}$ & $-0.114^{\star \star \star}$ & $-0.104^{\star * *}$ & $-0.136^{\star * *}$ \\
\hline & $(0.006)$ & $(0.009)$ & $(0.009)$ & $(0.007)$ & $(0.011)$ \\
\hline \multirow[t]{2}{*}{ finasset } & $-1.593^{* * *}$ & $-1.491^{\star * \star}$ & $-1.639^{* * *}$ & $-1.370^{* * *}$ & $-1.838^{* * *}$ \\
\hline & $(0.078)$ & $(0.101)$ & $(0.114)$ & $(0.071)$ & $(0.196)$ \\
\hline \multirow[t]{2}{*}{ lncominsurance } & -0.002 & 0.001 & $-0.007^{\star}$ & -0.001 & -0.009 \\
\hline & $(0.002)$ & $(0.003)$ & $(0.004)$ & $(0.002)$ & $(0.006)$ \\
\hline \multirow[t]{2}{*}{ work } & 0.005 & $0.075^{\star *}$ & $-0.088^{\star *}$ & 0.047 & -0.054 \\
\hline & $(0.029)$ & $(0.037)$ & $(0.045)$ & $(0.031)$ & $(0.056)$ \\
\hline \multirow[t]{2}{*}{ hospital } & $0.052^{\star * *}$ & 0.016 & $0.087^{\star * *}$ & $0.034^{\star *}$ & $0.073^{* *}$ \\
\hline & $(0.017)$ & $(0.022)$ & $(0.024)$ & $(0.017)$ & $(0.034)$ \\
\hline \multirow[t]{2}{*}{ socialnet } & $0.747^{\star * *}$ & $0.574^{\star * *}$ & $0.877^{\star \star *}$ & $0.525^{\star * *}$ & $1.107^{\star * \star}$ \\
\hline & $(0.017)$ & $(0.022)$ & $(0.026)$ & $(0.017)$ & $(0.037)$ \\
\hline Model & Tobit & Tobit & Tobit & Tobit & Tobit \\
\hline $\begin{array}{c}\text { Provincial } \\
\text { dummy variable }\end{array}$ & controlled & controlled & controlled & controlled & controlled \\
\hline $\mathrm{N}$ & 8720 & 3985 & 4565 & 5339 & 3381 \\
\hline
\end{tabular}

Footnote: The significance level in the table, “*” indicates that the p value of the corresponding statistic is less than 0.1 , “**” means $p$ is less than 0.05 , “***” means $p$ is less than 0.01 , the same below.

\section{1) $\mathrm{H} 1$ Test}

Regression results (1) shows the regression results of the overall sample using obit model. From the regression results (1), the regression coefficients of the main variables of the corresponding model in the total samples can be obtained. The results show that the effect of basic endowment insurance on the degree of family debt was positively significant. That is to say, the degree of debt of insured families was 10.9 percentage points higher than that of non-insured families. The above empirical results are basically consistent with $\mathrm{H} 1$. So the basic endowment insurance, as one of the main safeguard way of Chinese family pension, has a significantly positive effect on household debt level.

\section{2) H2 Test}

The current basic endowment insurance system has adopted different system designs for different types of employment groups in urban and rural areas. Therefore, it is necessary to take the types of household registration as the classification standard to investigate the impact of basic endowment insurance on the urban and rural household debt behavior. The regression (2) and (3) list the results of urban household and rural household. Seen from regression (4), the basic endowment insurance has a significant positive impact on the debt level of rural families, but as opposed to this, the coefficient of the core explanatory va- 
riable is not significant in urban household. This is roughly consistent with $\mathrm{H} 2$.

This shows that the incentive principle of social endowment insurance for non-working residents has significantly enhanced the income expectation level of rural residents, thus making the income effect stronger than the crowding out effect. The reason why this positive correlation does not exist on urban household, is that basic pension wealth is rising too slowly to keep pace with prices. In addition, compared with rural households, it is more difficult for urban families to borrow funds from other people and financial institutions. With the stronger demand for investment debt in urban households, the income effect is not obvious.

3) H3 Test

Families with different income levels have different risk tolerance and different expectations for future income. This will lead to different constraints on the payment burden and different subjective evaluation of the future benefits brought by insurance. Therefore, in this paper, the per capita disposable income of urban residents in 2014 surveyed by the national bureau of statistics is used as the standard to divide the group into the high-income one and the low-income one for regression. The results are shown in regression (4) and (5), which in consistent with $\mathrm{H} 3$.

The coefficient of the core explanatory variable for both High-income families and Low-income families is significant. But the significance of High-income families is stronger than another. The reasons are as follows: Firstly, although lower payment level may lead to lower future expected income, pension insurance still has a positive impact on household debt due to the higher risk of labor income. However, the relatively large proportion of endowment insurance contribution also enhanced the crowding out effect, thus offsetting most of income effects. Moreover, low-income families are more inclined to rely on social network, an informal insurance system, to obtain free loans from third parties, which can be referred from the significant coefficient of socialnet. So the influence of basic endowment insurance, a formal insurance system, on the debt behaviors of low-income families will be greatly weakened.

\subsection{Robust Test}

Through the above empirical analysis, basic pension insurance has a significant impact on household debt behaviors, but meanwhile, the degree of household debt will also affect the family's insurance behavior. In this case, there exists endogenous problems. In addition, there are problems such as missing factors such as family members' risk appetite and work. This article will use the instrumental variable method to solve potential endogenous problems.

Referring to the research of Kang Shulong [7], this paper also selects the average contribution rate and institutional dependency rate of the basic endowment insurance for urban employees in the province where the family is located as the instrumental variable of the proportion of households participating in the insurance. 
The average contribution rate of the province where the family is located is defined as follows: (the collection and payment of the basic pension scheme for employees in the same year/the number of people paying for the basic pension scheme for employees in the same year)/the average salary of urban employees in the previous year.

The institutional dependency rate of the province where the family is located is defined as: Number of retirees/number of participants paying for insurance. The data of above indicators comes from the China Statistical Yearbook 2014 and the China Pension Development Report 2015. Then the instrumental variables are used to regression the above regression based on the IV-Tobit model, thus testing the robustness of the model results.

In order to ensure the validity of the instrumental variables, this paper conducts a series of tests on the exogenous and correlation of instrumental variables under the overall sample. First, the $\mathrm{p}$ value in the unrecognized testis significantly zero, so the unrecognizable null hypothesis is rejected. Second, the Cragg-Donald Wald F statistic in the weak tool variable test is 101.912 , which is much higher than the critical value of the $10 \%$ significance level error tolerance. This indicates that the correlation between the instrumental variable and the endogenous explanatory variable is better. The Hausman test results also show that the IV regression fits better.

Table 3 shows the result of the instrument variables. Compared with Table 2, the coefficient of the core explanatory variable did not change significance greatly. The difference is that the core coefficient of the low-income family group obtained by the instrumental variable method changes from significant at the level of $10 \%$ to insignificant. This is because the crowded out effect brought by comparatively higher premium completely offset the income effects after eliminating endogeneity, which is more close to the reality.

Consequently, it can be considered that the empirical results are robust under this condition.

Table 3. The instrument variables test.

\begin{tabular}{cccccc}
\hline & Tobit & $\begin{array}{c}\text { Urban } \\
\text { families }\end{array}$ & $\begin{array}{c}\text { Rural } \\
\text { families }\end{array}$ & $\begin{array}{c}\text { High-income } \\
\text { families }\end{array}$ & $\begin{array}{c}\text { Low-income } \\
\text { families }\end{array}$ \\
\hline \multirow{3}{*}{ eldinsurance } & $(1)$ & $(2)$ & $(3)$ & $(4)$ & $(5)$ \\
& $0.413^{* *}$ & 0.257 & $0.483^{* *}$ & $0.488^{* *}$ & 0.250 \\
gender & $(0.185)$ & $(0.681)$ & $(0.193)$ & $(0.197)$ & $(0.354)$ \\
& -0.010 & 0.014 & -0.031 & -0.008 & -0.019 \\
age & $(0.016)$ & $(0.022)$ & $(0.025)$ & $(0.016)$ & $(0.032)$ \\
& $-0.002^{* *}$ & -0.003 & 0.000 & -0.001 & -0.003 \\
edu & $(0.001)$ & $(0.002)$ & $(0.001)$ & $(0.001)$ & $(0.002)$ \\
& $0.007^{* * *}$ & $0.010^{* * *}$ & 0.004 & $0.004^{* *}$ & $0.013^{* * *}$ \\
& $(0.002)$ & $(0.003)$ & $(0.003)$ & $(0.002)$ & $(0.005)$ \\
\hline
\end{tabular}




\begin{tabular}{|c|c|c|c|c|c|}
\hline \multicolumn{6}{|l|}{ Continued } \\
\hline \multirow[t]{2}{*}{ rural } & $-0.067^{\star * *}$ & $-0.051^{\star *}$ & -0.019 & $-0.066^{* * *}$ & -0.082 \\
\hline & $(0.022)$ & $(0.026)$ & $(0.050)$ & $(0.022)$ & $(0.055)$ \\
\hline \multirow[t]{2}{*}{ marriage } & -0.016 & 0.002 & 0.003 & -0.004 & -0.031 \\
\hline & $(0.029)$ & $(0.037)$ & $(0.044)$ & $(0.029)$ & $(0.052)$ \\
\hline \multirow[t]{2}{*}{ population } & 0.003 & 0.002 & 0.007 & -0.004 & $0.021^{*}$ \\
\hline & $(0.005)$ & $(0.006)$ & $(0.007)$ & $(0.005)$ & $(0.011)$ \\
\hline \multirow[t]{2}{*}{ health } & 0.010 & 0.002 & 0.009 & -0.004 & $0.026^{\star *}$ \\
\hline & $(0.007)$ & $(0.009)$ & $(0.009)$ & $(0.007)$ & $(0.013)$ \\
\hline \multirow[t]{2}{*}{ lnincome } & $-0.115^{\star * *}$ & $-0.181^{\star *}$ & -0.060 & -0.181 & 0.020 \\
\hline & $(0.038)$ & $(0.072)$ & $(0.045)$ & $(0.303)$ & $(0.060)$ \\
\hline \multirow[t]{2}{*}{ lnincome2 } & $0.005^{\star * *}$ & $0.010^{* *}$ & 0.002 & 0.011 & -0.003 \\
\hline & $(0.002)$ & $(0.004)$ & $(0.003)$ & $(0.013)$ & $(0.004)$ \\
\hline \multirow[t]{2}{*}{ lnconsume } & $0.111^{\star * *}$ & $0.094^{\star * \star}$ & $0.116^{* * *}$ & $0.083^{\star * *}$ & $0.127^{\star \star \star}$ \\
\hline & $(0.012)$ & $(0.018)$ & $(0.016)$ & $(0.012)$ & $(0.024)$ \\
\hline \multirow[t]{2}{*}{ lnhouseasset } & $-0.117^{\star * *}$ & $-0.121^{\star \star \star}$ & $-0.118^{\star * *}$ & $-0.107^{\star * *}$ & $-0.136^{\star * *}$ \\
\hline & $(0.008)$ & $(0.012)$ & $(0.011)$ & $(0.010)$ & $(0.013)$ \\
\hline \multirow[t]{2}{*}{ finasset } & $-1.600^{* * *}$ & $-1.507^{\star * *}$ & $-1.640^{* * *}$ & $-1.379^{\star * *}$ & $-1.842^{* * *}$ \\
\hline & $(0.113)$ & $(0.140)$ & $(0.175)$ & $(0.105)$ & $(0.340)$ \\
\hline \multirow[t]{2}{*}{ Incominsurance } & -0.004 & -0.000 & $-0.008^{\star *}$ & -0.002 & -0.009 \\
\hline & $(0.002)$ & $(0.004)$ & $(0.004)$ & $(0.002)$ & $(0.006)$ \\
\hline \multirow[t]{2}{*}{ work } & -0.083 & 0.008 & $-0.167^{\star \star}$ & -0.086 & -0.088 \\
\hline & $(0.059)$ & $(0.233)$ & $(0.065)$ & $(0.072)$ & $(0.094)$ \\
\hline \multirow[t]{2}{*}{ hospital } & $0.052^{* * *}$ & 0.019 & $0.085^{* * *}$ & $0.040^{* *}$ & $0.073^{* *}$ \\
\hline & $(0.017)$ & $(0.024)$ & $(0.026)$ & $(0.018)$ & $(0.035)$ \\
\hline \multirow[t]{2}{*}{ socialnet } & $0.740^{\star * *}$ & $0.573^{* * *}$ & $0.866^{\star \star *}$ & $0.525^{\star \star \star}$ & $1.101^{\star \star \star}$ \\
\hline & $(0.030)$ & $(0.035)$ & $(0.046)$ & $(0.027)$ & $(0.066)$ \\
\hline Model & IV-Tobit & IV-Tobit & IV-Tobit & IV-Tobit & IV-Tobit \\
\hline $\mathrm{N}$ & 8720 & 3985 & 4565 & 5339 & 3381 \\
\hline
\end{tabular}

\section{Conclusions}

This paper uses the cross-sectional data of the 2014 CFPS to examine the impact of basic pension insurance on residents' debt levels, in order to enrich the relative studies about factors influencing residents' debt behavior. According to the existing research, the basic pension insurance affects the residents' debt behavior through the income effect and the crowding out effect.

This paper examines three hypotheses derived from empirical observations and theoretical analysis by the Tobit model. Firstly, the basic pension insurance has a significant positive impact on the degree of residents' debt. Secondly, although the behavior of participation in the basic old-age insurance has a positive 
incentive effect on the degree of rural households' debt, it has no significant effect on the degree of urban households' debt. Thirdly, the insured behavior will increase the debt ratio of high-income families. Although insured behavior also has a positive impact on low-income families, this effect is not as significant as high-income households.

Finally, this paper uses the IV-Tobit model to test the robustness of the above regression results. The average contribution rate and the institutional dependency rate of the province where the family is located are selected as instrumental variables to solve the endogenous problem of model. The test results show the research conclusion is steady.

Based on the above conclusions, the continuous decline in the household savings rate in recent years illustrates the continuous improvement of the social security system. And improving the coverage of basic old-age insurance is one of the important measures. The aim of expanding the coverage of basic pension scheme is to implement its risk sharing and life security functions. However, it also has a negative externality to the family, which causes the rise of household debt ratio. Of course, the rise of the leverage ratio of residents reflects the optimization of China's consumption structure and the improvement of financial efficiency to a certain extent. At the same time, we must also pay attention to preventing the economic risks caused by the excessive growth of the leverage ratio of residents.

Because of the limits of micro-database and my knowledge, there may be omissions or errors in variable selection, such as householder's risk appetite. Additionally, this paper fails to use dynamic panel data to reveal the long-term changes in the relationship between basic endowment insurance and household debt, which is also the direction that this study can expand in the future.

\section{Conflicts of Interest}

The author declares no conflicts of interest regarding the publication of this paper.

\section{References}

[1] Sebastian, B. and Young, G. (2003) The Rise in US Household Debt: Assessing Its Causes and Sustainability. Bank of England Working Paper 206.

[2] Zhang, J.J. (2003) Farmers' Social Capital and Its Impact on Credit Behavior-An Empirical Analysis Based on Survey of 397 Farmers in Henan Province. Agricultural Economic Problems, No. 9, 28-34.

[3] Crook, J. (2011) The Demand for Household Debt in the USA: Evidence from the 1995 Survey of Consumer Finance. Applied Financial Economics, 11, 83-91. https://doi.org/10.1080/09603100150210291

[4] Hu, Z., Yang, H.L. and Zang, R.H. (2015) Household Debt Heterogeneity and Analysis of Influence Factors: Microeconomic Evidence in China. Journal of Business Economics, No. 9, 67-75.

[5] Wu, W.X., Xu, Q. and Bai, X.H. (2013) A Comparative Study of Group Differences 
among Debt Decision-Making of Chinese Households. Journal of Finance and Business, No. 3, 19-29.

[6] Wu, W.X., Shao, X.F. and Tao, L.B. (2016) Will Family Wealth Inequality Enlarge Itself?-Based on the Analysis of Family Financial Leverage. Management World, No. 9, 44-54.

[7] Kang, S.L., Yu, H.Y. and Wang, Z.Q. (2017) The Basic Pension Scheme and Urban Household Consumption: An Analysis from the Perspective of Liquidity Constraints. The Journal of World Economy, No. 12, 165-188.

[8] Ma, G.R. and Zhou, G.S. (2017) The Impacts of New Rural Pension Program on Household Saving: Evidence from CFPS. Economic Research Journal, No. 11, 116129.

[9] Zelde, S. (1989) Consumption and Liquidity Constraints: An Empirical Investigation. Journal of Political Economy, 97, 305-346. https://doi.org/10.1086/261605

[10] Hubbard, R.G. (1988) Uncertain Lifetimes, Pensions and Individual Saving. Nber Working Papers, 175-210.

[11] Cox, D. and Jappelli T. (1993) The Effect of Borrowing Constraints on Consumer Liabilities. Journal of Money Credit \& Banking, 25, 197-213. https://doi.org/10.2307/2077836

[12] He, L.F., Wu, W.X. and Xu. Q. (2012) Analysis of China's Household Debt Status, Structure and Its Influencing Factors. Journal of Huazhong Normal University, No. 1, 59-68.

[13] He, L.X., Feng, J. and Sato. H. (2012) Pension Reform and Household Saving: the Chinese Case. Economic Research Journal, No. 10, 117-130.

[14] Nie, J.L. and Zhong, Z.B. (2017) Research on the Welfare Effects of Social Endowment Insurance to Rural Elderly-Based on the Investigation In Hubei Province. Social Security Studies, No. 1, 63-73. 